\title{
1
}

\section{PRME - PRINCIPLES FOR RESPONSIBLE MANAGEMENT EDUCATION}

\section{Towards transforming leadership education}

\section{Mette Morsing}

\subsection{The need for leadership education to focus on societal betterment}

Business school education plays a fundamental role for the business strategies, economic tools and decision-making frameworks that are put into practical business reality every day by managers in millions of businesses today. Indeed, the reach of business school is unprecedented with millions of undergraduate and graduate students as well as professional leaders engaging in leadership and executive training at business schools.

With a UN mandate in 2017, the Principles for Responsible Management Education (PRME), an initiative of the United Nations, is set into existence to raise the sustainability profile of business schools around the world. Today, we are a UN movement of more than 800 signatory schools with access to an ever-evolving network of around 3 million students and 200,000 faculty. According to recent estimates, more than 15,000 business 
schools exist in the world today (see Jim Walsh's chapter in this book). Unfortunately, no such assessment of the total number of business school students at a global scale at any moment in time seems currently available. But the number of business schools in the world and the impact that they have on students is daunting to imagine. The impact on the direction of the world that our students have is ultimately the goal of PRME. Our students can change that direction for the better as they enter private and public organizations to make influential decisions and create real on-theground economic impact for social and environmental life.

Business education comes with a huge opportunity to change the world. As a voluntary initiative, Principles for Responsible Management Education (PRME), with more than 800 signatory schools and universities in support of education, research and operational activities toward responsible management and sustainable development, provides a promising global platform. Leadership education institutions are the centerpiece on the 'supply side' of business talent. This is where business mindsets and frameworks are cultivated, challenged and advanced. This is where new ideas can be scaled and can contribute to form the direction of the world.

One important centerpiece informing leadership education concerns the ongoing debate on what the purpose of business is. In this debate, the introduction of the stakeholder model in the early 1980s (Freeman, 1984) was a turning point. Importantly, it redirected the debate from a focus on serving shareholders, the legal owners of the corporation, to emphasize the purpose as being serving stakeholders more generally.

Today, the stakeholder model is being redefined. Putting the corporation at the center of the stakeholder model was the norm in the early days when the stakeholder model was first introduced to management scholarship. This stakeholder model from the 1980s presents a corporate-centric model and does not necessarily question the 'growth assumption' as a corporate goal. It is supportive of an economic logic, where the corporation takes into consideration its stakeholders in order for itself to grow. Today, there is a new urgent request from not only businesses but from business school students to challenge the global assumption of growth and the positioning of the corporation at the center of such a model. Recently, this has been referred to as 'purpose-driven business'.

The notion of 'purpose-driven business' defines the purpose of business as first and foremost being in the service of society. The ultimate goal 
of any business - independent of size, industry or geography - is to serve societal betterment. This changes the positioning of business as being at the center of the stakeholder model. If the ultimate purpose of business is to serve society, society must be at the center of the model and business is one of the many stakeholders working with a goal of improving society.

In our education of leadership students, we need to rewrite the curriculum to fit this purpose. Our students must develop a mindset where society is at the center of the stakeholder model and the frameworks, analyses and models they are taught must serve this 'society-centric' redefined stakeholder model.

Putting society at the center has a number of implications for the way we teach business. It challenges the basic ethical standards for norms of trust, responsibility and fairness that guide managerial practice. And it challenges what is considered 'success' in business and how to become an accomplished 'responsible leader'.

\subsection{The idea of leadership education and the professionalization of the 'manager'}

The idea of responsible leadership is not new. In fact, the idea is at least as old as the business school itself. The establishment of North American business schools in the early 20th century with an ambition of professionalizing management came with an articulated effort to frame business education as "possessing a higher purpose than mere "moneymaking"' (Khurana and Penrice, 2010: 5). Just as education of medical doctors and lawyers installed a sense of social duty for society in their students, so too were ideas about educating a 'socially conscious leadership for the nation' (ibid) and expectations to train business professionals to take into consideration social implications of their occupation and to develop a "heightened sense of responsibility' (ibid) specifically articulated for business education. In the European university system that came to be a role model for the European business school, the 18th-century German Humboldtian idea of higher education emphasized the dual purpose of Bildung and Ausbildung. The basic ambition of Humboldt was - for the betterment of society - to educate people to become world citizens with a holistic outlook, to become autonomous individuals developing their own reasoning powers to decide between right and wrong (Bildung), while at the same time providing 
them with more specific professional skills required through schooling (Ausbildung). Ingrained in the Humboldtian ideal was the acknowledgment of being skillful and 'well-informed':

There are undeniably certain kinds of knowledge that must be of a general nature and, more importantly, a certain cultivation of the mind and character that nobody can afford to be without. People obviously cannot be good craftworkers, merchants, soldiers or businessmen unless, regardless of their occupation, they are good, upstanding and - according to their condition - well-informed human beings and citizens. If this basis is laid through schooling, vocational skills are easily acquired later on, and a person is always free to move from one occupation to another, as so often happens in life.

Quoted in Profiles of educators: Wilhelm von Humboldt (1767-1835) by Karl-Heinz Günther (1988; doi:10.1007/BFo2192965)

Management education has been critiqued for having become a matter of training 'business technicians', as Joseph Willits, Wharton School's former Dean, put it many years ago. His ambition was to make it clear that educating business leaders with 'a sense of statesmanship' had become underappreciated yet was most urgently needed to develop healthy societies (Willits [1934] cited in Khurana and Penrice, 2011: 5/6). Along the same lines of critique, the value of business schools' existence has been questioned profoundly (Parker, 2018). The critique points to the ideology and norms business schools set for students and alumni to focus primarily on their own personal rewards as the most important goal instead of teaching them how to make business a leverage to address the global challenges. Basically, it is argued, business schools are educating managers to favor shareholder value and deprioritize societal development. Others argue that the reason for why the world is not on track to achieve the SDGs is that 'sustainable development' is not a self-organizing property of market-based economic systems, which some market economists tend to promote and which, oftentimes, permeate the curriculum. As stated in the TWI2050 Report,

Market-based economic growth alone is rarely socially inclusive and environmentally stable. Without countervailing policies, markets are often reasonably efficient but also highly unfair making the rich richer and the poor poorer. Moreover, producers and consumers rarely have the incentive to protect the air, water, soils, and climate, since most of the damage 
they cause is incurred by others, including future generations, rather than themselves.

In other words, markets thrive on exploring public goods while underproviding society with new public goods. 'The challenge is therefore', as stated in the TWI2050 Report, 'to re-embed markets and shape them towards the sustainability goals' (TWI2050 Report: 11).

Business schools are asked for critical self-reflection when the markets' relation to society is under critique. In the aftermath of the 2007 financial crisis, business schools were a target of ethical inquiry and they are now again a target as businesses are seen to not contribute enough to reduce environmental pollution and improve labor standards and human rights.

The new turn comes with a conspicuous request to not only reshape but to actually 'transform markets' toward a purpose of sustainable development of the planet and its people in the long-term consideration for the world and the many next generations. The rise in business scandals and disrespectful corporate behavior toward the environment and human rights contributes to a rising skepticism toward business. Businesses are, sometimes, seen to contribute to worsening the situation in spite of claimed good intentions. Our colleagues from the natural sciences are providing science-based proof about the scarcity of the planet's resources, notably evidenced and forecasted by the 'planetary boundaries' framework, and are urging business school scholars to establish the green agenda at the very core of the business school curriculum (Rockström). At the same time, the need to also bring ethics and social skills into the classroom is emphasized. A report on 'CEO Success', from management consultants Strategy\&, published in 2019, reveals that for the first time since 2007 'more CEOs had to leave their job due to ethical lapses and misconduct (39\%) than due to poor financial performance (35\%) or conflicts with the board (13\%)' (Rasche, 2019). Across these observations, urges and critiques, there is a new shared understanding: that while business is the source of global problems, business is also one of the important partners in solving them (Guterres, 2021) and accordingly there is an urgent need to advance the managerial skillset.

In that context, it seems natural to ask about the role of those institutions that educate and train the leaders who make those strategically 
impactful decisions to invest, divest, source, produce and recruit in these businesses. It has been stated again and again over the past few years that it is time to reimagine the role of the business school - that it is time to ask the basic question of how business schools can establish the idea in our students to consistently challenge themselves to ask what their companies can do for society instead of what society can do for their companies and their owners.

Management education is a normative endeavor in which assumptions about right and wrong ways of leading people and making decisions underpin the curriculum and not least the hidden curriculum, that is, the unwritten, non-articulated and often unintended values and perspectives that students are exposed to (Blasco, 2020). As educators, we communicate social and behavioral expectations to our students and set a tone for ethical and social interactions in the classroom and beyond, regardless of whether we have planned to do so or not. Nitin Nohria, former Dean of Harvard Business School, puts an emphasis on the responsibility of the business school classroom this way: "Today's business school students who don't identify and correct what they are doing wrong are tomorrow's chief executives making the same mistakes with a large company" (Nohria, 2019). In the classroom, through education, profound norm-setting, analytical framing of problems and solutions, and not least role modeling, business-school students are taught how to navigate in the global and local markets: how to manage, what to decide and whom to impact in what ways.

The classrooms in higher education have real-life and direct implications. A recent study shows how an only two-week long Chicago-style economics course influenced how judges started to use more economic language and rules against regulators, which led to harsher sentences overall and even years after completing the course. The study also shows how this effect spread to their peers (Ash, Chen and Naidu, 2019). Classrooms and their explicit and implicit curricula are not trivial matters. They matter.

\subsection{Educating world citizens}

Since the 2007 mandate from the UN Secretary-General, the role of PRME has been to advance the idea of responsible leadership via management education. PRME serves as the main UN-supported initiative to advance 
education on responsible leadership and sustainable development. Since its launch, PRME has been a convening platform for knowledge exchange on responsible management education with a vision to create a global movement and thought leadership on responsible management education. In this mandate to PRME from the Secretary-General of the United Nations, there is no uncertainty that serving societal betterment is the end goal. This comes with a responsibility to inspire education of responsible leaders to become 'world citizens' with the skills and the mindset to address urgent problems of climate change, rising inequalities and disregard for human rights. It is often said that we already have the technologies and the skillset (i.e., via the Ausbildung) needed to solve these global challenges but we have not yet the global governance structures and the mindset (i.e., the Bildung) that enable us to actually do it.

PRME has an important and exciting journey ahead and a huge responsibility to contribute to transforming leadership education with the purpose of educating the kind of leaders that the world needs. We need to work actively on many fronts. I will finish this chapter by pointing towards three overall areas that we as educators specifically need to focus on.

First, we need to focus on the content we teach our students: we must redefine what it means to be a successful and responsible leader. We need to rewrite our textbooks and put societal betterment at the center as the object for what it means to be a successful leader.

Second, we need to develop new pedagogies to advance innovative thinking and creative solutions for our students to develop the competence to address the world's complex wicked problems. We must advance a holistic skillset as we educate the world's future managers.

Third, we need to develop new ways of assessing the impact of our business schools and universities, and engage the wider ecosystem in promoting more relevant and timely ways of accounting for our impact that are in line with the needs of the world today.

The good news is that in many business schools and universities of the world, deans are responding to the critique with transformational plans of curriculum change and pedagogical development. Inspired by other professions, some business school deans are now asking their students to take an oath at their graduation about being socially responsible businessmen and women, to install a sense of respect and professional obligation to 
serve society. Other business schools have changed their visions and strategies and have integrated ambitions of educating youth to serve the idea of 'business for society'. The very basic idea that we educate students to understand that business is a means and societal betterment is the end and not the other way around - often requires a dramatic shift in strategy. And such a shift in strategy comes with new obligations and transformations. It is not 'just words' on paper. It has real implications for educational strategies and direction.

Interestingly, what we are witnessing today in higher management in many business schools is a turn to - or a re-turn to - giving emphasis to the original early 19th-century business school purpose of producing 'socially conscious business leadership' (Khurana and Penrice, 2010: 3), 'who will handle their current business problems in socially constructive ways' (Donham, 1927: 24). But while this carried a slightly patriarchal tone in the 1920s, today the idea is oriented toward what we may refer to as a 'collaborative turn' and what others have labeled a 'cooperative advantage' (Strand and Freeman, 2015).

Today, business schools have the potential to significantly set a global agenda to advance responsible management and to support the transformation of the Sustainable Development Goals (SDGs) from words into action. As generators of novel scientific research and based on a platform of research-based education, business schools are trusted by the general public to set 'the tone' for future responsible decision-making - beginning in the classroom.

The mission for PRME is to generate a movement to transform management education - to evidence, inspire and impact the role of business schools and universities for sustainable development. To reach this mission, PRME will continue to connect, collaborate and engage with partners all over the world.

I opened this chapter by emphasizing the normative implications of leadership education on how business serves as agents for the benefit of the world. I end this chapter by stating that I acknowledge the daunting task ahead of us, but noting that I am cautiously optimistic, as I see how a growing number of leadership education institutions and the ecosystem of ranking, rating and accreditation institutions are directing attention to the fundamentally needed reorientation of leadership education. 


\section{References}

Ash, E., Chen, D. L., \& Naidu, S. (2019) 'Ideas have consequences: The impact of law and economics on american justice,' Center for Law \& Economics Working Paper Series, 4 [online]. Available at: https://doi.org/10.3929/ ethz-b-000376884 (Accessed 17 May 2021).

Blasco, M. (2020) 'The hidden curriculum: can the concept support responsible management learning?'in Laasch, O., Parkes, C. \& Brown, K.G.(eds.) The SAGE Handbook of Responsible Management Learning Q Education. London: Sage.

Donham, W.B. (1927) 'The social significance of business,' Harvard Business Review, 5(4), 406-419.

Freeman, R.E. (1984) Strategic management: A stakeholder approach. New York: Cambridge University Press.

Günther, K.H. (1988) 'Profiles of educators: Wilhelm von Humboldt (17671835),' Prospects, 18(1), 127-136. [online]. Available at: https://doi.org/ 10.1007/BFo2192965 (Accessed 17 May 2021).

Guterres, A. (2021) Enhanced cooperation between the United Nations and all relevant partners, in particular the private sector: Report of the SecretaryGeneral.[online]New York: United Nations, pp. 1-17. Available at: https:// undocs.org/en/A/76/319 (Accessed 17 May 2021).

Khurana, R. and Penrice, D. (2011)'Business Education: The American Trajectory,'inMorsing, M. and Alfons S. Rovira, A.S.(eds.) Business Schools and Their Contribution to Society. London: SAGE Publications Ltd, pp. 3-15. Available at: http://www.doi.org/10.4135/9781446250822.n1 (Accessed 17 May 2021).

Nohria, N. (2019) 'Business schools have a vital role in teaching trust,' Financial Times, 13 February [online]. Available at: https://www-ft-com.proxy.choate. edu/content/92fb59fo-2dfo-11e9-8od2-7b637agerbar (Accessed 17 May 2021).

Parker, M. (2018) 'Why we should bulldoze the business school,' The Guardian, 27 April [online]. Available at: https://www.theguardian.com/news/2018/ apr/27/bulldoze-the-business-school (Accessed 17 May 2021).

Rasche, A. (2019) 'More CEOs Sacked For Ethical Failure Than For Poor Financial Performance,'The Business of Society, 5 June [online]. Available at: http://www.bos-cbscsr.dk/2019/06/05/ceos-ethical-failure/ (Accessed 17 May 2021). 
Rockström, J. et al. (2009) 'Planetary boundaries: exploring the safe operating space for humanity,' Ecology Q Society, 14(2) [online]. Available at: https:// www.stockholmresilience.org/download/18.8615c78125078c8d3380002197/ ES-2009-3180.pdf (Accessed 17 May 2021).

Strand, R., \& Freeman, R. E. (2015) 'Scandinavian cooperative advantage: The theory and practice of stakeholder engagement in Scandinavia,' Journal of Business Ethics, 127(1), 65-85.

TWI2050 - The World in 2050 (2018) Transformations to Achieve the Sustainable Development Goals. [online] Laxenburg: The World in 2050 initiative,International Institute for Applied Systems Analysis (IIASA), pp.1-157. Available at: http://pure.iiasa.ac.at/id/eprint/15347/1/TWI2050_ Reporto81118-web-new.pdf (Accessed 17 May 2021). 